\title{
Allometric larval growth of the bottom-dwelling catfish Lophiosilurus alexandri Steindachner, 1876 (Siluriformes: Pseudopimelodidae)
}

\author{
Gabriel Caetano Guimarães de Mello ${ }^{1}$, José Enemir dos Santos ${ }^{1}$, Rodrigo José \\ Guimarães-Cruz ${ }^{1}$, Alexandre Lima Godinho ${ }^{2}$ and Hugo Pereira Godinho ${ }^{1}$
}

We investigated the early life growth pattern of pacamã, Lophiosilurus alexandri, a catfish endemic to the rio São Francisco basin, Brazil. Pacamã larvae were kept in a galvanized trough for 29 days after hatching. We collected approximately 10 larvae daily (total number $=285$ ). We obtained from each specimen the total length (independent variable) and 11 other body measurements (dependent variables). We performed linear regressions on the log-transformed data to determine the growth pattern of the body measurements and the respective inflexion point on the growth curves. Except for trunk length, trunk width and yolk sac volume, the remaining body measurements showed a positive allometric growth coefficient up to the respective IP followed by a decrease in the rate of relative growth afterwards. Although trunk width presented a positive allometric growth, no significant inflexion point was detected. The dorsal-ventral head flattening seen in the adult pacamã was quickly expressed in the larvae as indicated by the large allometric growth of head width. Maxillary barbels showed the highest growth rate. The exceptionally high growth rates of eyes and maxillary barbels and the acquired ability to capture prey (as suggested by mouth length growth) strengthened the hypothesis of growth priorities in which the most essential organs develop first.

Investigamos o padrão de crescimento inicial do pacamã, Lophiosilurus alexandri, um bagre endêmico da bacia do rio São Francisco, Brasil. Larvas de pacamã foram mantidas numa canaleta horizontal de metal galvanizado durante 29 dias após a eclosão. Diariamente, coletamos circa 10 larvas (número total $=285$ ) das quais obtivemos o comprimento total (variável independente) e 11 outras medidas corporais (variáveis dependentes). Fizemos regressões lineares nos dados log transformados para determinar o padrão de crescimento das medidas corporais e respectivo ponto de inflexão das curvas de crescimento. Exceto comprimento do tronco, largura do tronco e volume do saco vitelino, as demais medidas corporais apresentaram crescimento alométrico positivo até o respectivo ponto de inflexão, seguido de redução na taxa relativa de crescimento. Embora a largura do tronco apresentasse crescimento alométrico positivo, não foi detectado um ponto de inflexão significativo. O achatamento dorso-ventral da cabeça, presente nos adultos, mostrou-se evidente nas larvas com o acentuado crescimento alométrico de sua largura. Os barbilhões maxilares exibiram a maior taxa de crescimento. $\mathrm{O}$ extraordinário crescimento dos olhos e dos barbilhões maxilares e a habilidade adquirida para a captura de presas (como sugere o crescimento do comprimento bucal) reforçam a hipótese de prioridade de crescimento em que os órgãos essenciais são os primeiros a se desenvolverem.

Keywords: Early life, Fish rearing, Larval development, Pacamã, Rio São Francisco.

\section{Introduction}

During early life of fishes, changes in growth rates occur, namely in the development of structures related to sensorial perceptions, gas exchange, swimming, and capture of food that result in abilities to overcome the hostile environment (Osse \& van den Boogaart, 1995; van Snik et al., 1997; Gisbert, 1999; Kupren et al., 2014). During ontogeny, fish larvae undergo niche shifts with consequences for their growth and development (Balon, 1975, 1999; Müller \& Videler, 1996;
Barriga \& Battini, 2009). The point where growth rates change (inflexion point, IP) can be a valuable indicator for transitions in the ecology of an organism and thereby helps to detect transitions in the ontogeny (Safran, 1992). Therefore, knowledge of these changing relationship between larva and environment is very useful in conservation and is likely important for fisheries and aquaculture management (Koumoundouros et al., 1995). Furthermore, morphometric analyses allow comparisons of various developmental stages between species, and together with other morphological traits,

${ }^{1}$ Pontifícia Universidade Católica de Minas Gerais, Programa de Pós-Graduação em Zoologia de Vertebrados, Av. Dom José Gaspar, 500, 30535-610 Belo Horizonte, MG, Brazil. (GCGM) mellogcg@gmail.com, (JES) enemir@pucminas.br, (RJGC) rodrigoictio@gmail. com, (HPG) hgodinho@ufmg.br (corresponding author)

${ }^{2}$ Universidade Federal de Minas Gerais, Centro de Transposição de Peixes, Av. Antônio Carlos, 6627, 31270-901 Belo Horizonte, MG, Brazil.godinhoal@gmail.com 
assist in the identification of species (Sanches et al., 1999). In this study, we expanded the previous work of GuimarãesCruz et al. (2014) on early growth of pacamã, Lophiosilurus alexandri Steindachner, 1876, to incorporate analyses of IPs of different larval body measurements.

The pacamã is a middle-sized, bottom-dwelling riverine catfish, weighing up to $8 \mathrm{~kg}$ and native to the rio São Francisco basin, Brazil (Sato \& Godinho, 1999). Adult pacamãs are entirely light brown with dark spots, bearing a strongly depressed wide head, small eyes, large mouth pointed upwards, and short body. They are fish-eating predators that sit and wait buried in the sand to ambush prey. They reproduce naturally in experimental ponds where they build nest, shed sticky large eggs, and exhibit male parental care (Sato \& Godinho, 1999; Sato et al., 2003). Pacamã larvae are adapted to low luminous habitats and are bottom-dwellers like the adults (Pedreira et al., 2012). Pacamã has been included in 2014 Brazilian red list in the category vulnerable due to population size reduction in, at least, $30 \%$ in the last three generations (Instituto Chico Mendes de Conservação da Biodiversidade (ICMBio), 2014).

There is an increasing interest in pacamã as aquaculture species due to its highly prized meat and apparent reduction of wild stocks caused by environmental impacts. Ecomorphological and culture experiments have been conducted envisaging the establishment of pacamã larval culture protocols (López \& Sampaio, 2000; Pedreira et al., 2008; Guimarães-Cruz et al., 2009; Pedreira et al., 2009; Santos \& Luz, 2009; Luz et al., 2011). Recently, Santos et al. (2013) published a valuable set of data on reproductive parameter of hormonally induced spawning pacamãs obtained in hatchery conditions.

The study aimed to determine the growth pattern (isometric or allometric) of body measurements of early life pacamãs raised in laboratory conditions. Our hypothesis is that early life growth of pacamã varies allometrically as a result of priorities for the development of structures and organs of greatest need.

\section{Material and Methods}

Fish rearing. We used naturally spawned individuals from an experimental fish pond of a governmental fisheries station (18 $11^{\circ} 58^{\prime \prime}$ S $\left.45^{\circ} 15^{\prime} 07^{\prime \prime} \mathrm{W}\right)$, State of Minas Gerais, Brazil. Approximately 600 newly hatched larvae from one female, were placed in a galvanized rearing trough in which they were maintained during the experiment (Guimarães-Cruz et al., 2009). The trough had $1.2 \mathrm{~m}$ in length, $0.35 \mathrm{~m}$ in width, and a bottom area of $0.43 \mathrm{~m}^{2}$, holding $42 \mathrm{~L}$ of water with continuous water flow set at the rate of $2.6 \mathrm{~L} \mathrm{~min}^{-1}$ (Luz et al., 2011). The water to the trough, supplied from the upstream Três Marias Reservoir on the rio São Francisco, had the following physical-chemical characteristics (mean \pm standard deviation) measured daily with a multiparameter water quality meter: temperature $\left({ }^{\circ} \mathrm{C}\right)=24.0 \pm 1.8, \mathrm{pH}=6.4 \pm 0.3$, conductivity $(\mu \mathrm{S}$ $\left.\mathrm{cm}^{-1}\right)=60.5 \pm 4.9$, and dissolved oxygen $\left(\mathrm{mg} \mathrm{L}^{-1}\right)=4.1 \pm 0.8$.
The larvae were exposed to the natural photoperiod, being illuminated by overhead fluorescent lights during the day. They were fed daily, at 8-9 am and 4-5 pm, ad libitum, with Artemia nauplii and pond-produced zooplankton collected daily with a $68 \mu \mathrm{m}$-mesh plankton net from the $6^{\text {th }}$ day after hatching (DAH) onwards. During feeding the water flow was interrupted to avoid the loss of Artemia nauplii and zooplankton. The trough was cleaned once a day by siphoning the bottom to remove waste. The experimental conditions given to the larvae in this work allowed them to perform growth similar to that obtained in a pacamã larval experiment conducted at same fisheries station (López \& Sampaio, 2000).

We examined $\operatorname{circa} 10$ larvae/day (total $=285)$, from day 0 (at hatching) to the $29^{\text {th }} \mathrm{DAH}$ collected for a previous study (Guimarães-Cruz et al., 2009). They were preserved in $10 \%$ formaldehyde solution for $4 \mathrm{~h}$ and stored in adequate, controlled conditions in $70 \%$ ethanol solution during 48 months prior to the measurements. We did not make any corrections due to shrinkage in the measurements made on the fixed individuals. However, we handled the larvae used in the present study in a similar manner so any eventual shrinkage due to fixative procedures would have been proportional among the individuals. We estimated a $6.9 \%$ shrinkage in total length of our measurements at earlypreflexion stage of development (1-2 DAH) as compared to those of Guimarães-Cruz et al. (2009) whose data were obtained immediately after storage of these larvae. Voucher specimens are deposited in the fish collection housed in the Museu de Ciências Naturais, Pontifícia Universidade Católica de Minas Gerais, Belo Horizonte (MCNIP-0116).

Stages of larval development. In order to increase accuracy on the timing of morphological descriptions, we categorized the larval development in preflexion, flexion, and postflexion stages, as indicated by the degree of notochord development (Oliveira et al., 2008).

Morphometric analysis. We used a stereomicroscope (Olympus SZ-ILK) with a micrometric ruler attached to the eyepiece to obtain morphometric measurements of each individual. The following body measurements (Fig. 1), taken to the nearest $0.1 \mathrm{~mm}$, were: total length (distance from the tip of the head to the posterior border of the caudal fin, TL), head length (distance from the tip of the head to the free edge of the operculum), head height (distance from the ventral border of the operculum to the dorsal border of the head), head width (distance between right and left borders of the head measured at the level the operculum), mouth length (distance between the tip and the angle of the mouth rim on one-sided view), eye diameter, maxillary barbel length (distance between barbel insertion to its free tip), trunk length (distance from the free edge of the operculum to a vertical plane drawn along the anus level), trunk height (distance between the dorsal and ventral border of the trunk measured at the anus level) trunk width (distance between 
the right and the left border of the trunk measured at the anus level), postanal length (distance from a transverse plane at the anus level to the posterior border of the caudal fin), yolk sac length (distance between the ends of its major axis), and yolk sac height (distance between the ends of its minor axis). We estimated the yolk sac volume (YSV) using the equation for a prolate spheroid $\mathrm{YSV}=4 / 3 \pi(\mathrm{H} / 2)^{2} \mathrm{~L} / 2$, where $\mathrm{H}=$ yolk sac height and $\mathrm{L}=$ yolk sac length (Blaxter \& Hempel, 1966).

To study the allometric growth pattern of each of eleven body measurements in relation to TL we used the equation $\log \mathrm{Y}=\log a+b \log \mathrm{TL}$, where $\mathrm{Y}=$ the body measurement under analysis, $a=$ intercept, and $b=$ allometric growth coefficient (Fuiman, 1983). We obtained $a$ and $b$ by linear regression. When growth of the body measurement is isometric, then $b=1$ for length or $b=3$ for volume. Allometric growth is positive when $\mathrm{b}>$ isometric value, or negative when $b<$ isometric value.

We obtained the inflexion point (IP) of the growth curve, i.e. the TL value where $b$ significantly changes, according to van Snik et al. (1997). In summary, we sorted the TL-Y data set according to increasing TL. Then, we calculated regressions lines for $\mathrm{TL}_{\min }$ until $\mathrm{TL}_{\text {intermediate }}$ and for $\mathrm{TL}_{\text {intermediate }}$ until $\mathrm{TL}_{\max }$, where $\mathrm{TL}_{\text {intermediate }}$ varied iteratively from $\mathrm{TL}_{\min }+$ 2 to $\mathrm{TL}_{\max }-2$. For the $b s$ of each pair of regression lines, we determined the $t$ value using the $\mathrm{t}$-test. We then determined the $p$-value for the largest $t$. If it was $\leq 0.05$, we used the correspondent $\mathrm{TL}_{\text {intermediate }}$ as IP. We also determined if $b$ statistically differed from the corresponding isometric value using the t-test at a significance level of 0.05 . We performed the analyses through an algorithm using the SAS software (SAS Institute, 1990).
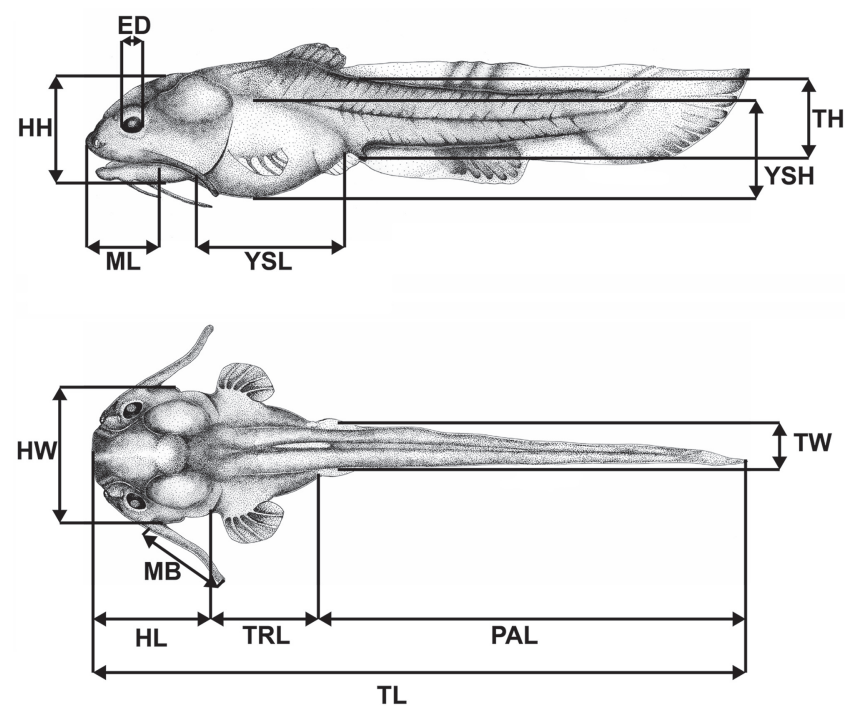

Fig. 1. Drawing of Lophiosilurus alexandri larvae (circa 13 mm TL, 8 DAH): total length (TL), head length (HL), head height $(\mathrm{HH})$, head width (HW), mouth length (ML), eye diameter (ED), maxillary barbel length (MB), trunk length (TRL), trunk height (TH), trunk width (TW), yolk sac length (YSL), yolk sac height (YSH), and postanal length (PAL).

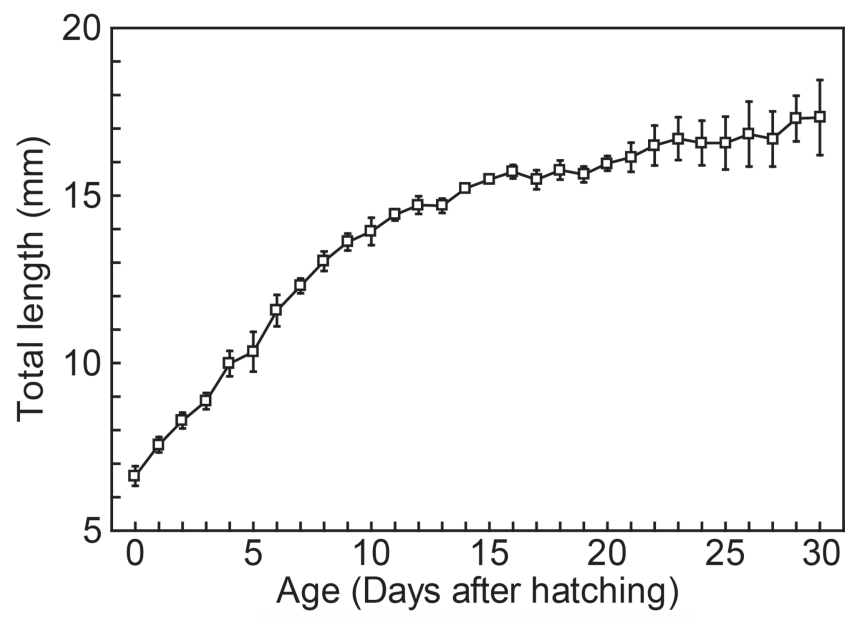

Fig. 2. Mean \pm standard deviation of total length of Lophiosilurus alexandri larvae in relation to age.

\section{Results}

Larval development. Pacamã TL ranged from $6.6 \pm 0.3$ $\mathrm{mm}$ TL at hatching to $17.3 \pm 1.1 \mathrm{~mm} \mathrm{TL}$ at the end of the period of study, 29 DAH (Fig. 2).

The preflexion stage extended from hatching to 3 DAH. On $1 \mathrm{DAH}$ (larval size: $7.6 \pm 0.2 \mathrm{~mm} \mathrm{TL}$ ), the larvae were transparent with no chromatophores, the notochord and myomeres were visible. On 2 DAH (larval size: $8.3 \pm 0.2 \mathrm{~mm} \mathrm{TL}$ ), the mouth and anus were opened and the buds of maxillary barbels were firstly seen. On 3 DAH (larval size: $8.9 \pm 0.2 \mathrm{~mm} \mathrm{TL}$ ), the retina became heavily pigmented, pectoral fins were macroscopically visible, and first skin chromatophores appeared. The process of yolk sac exhaustion occurred at a slower pace in this stage.

The flexion stage lasted from 4 DAH to 7 DAH. On 4 DAH (larval size: $10.0 \pm 0.4 \mathrm{~mm} \mathrm{TL}$ ), caudal fin rays were visible and the notochord bending had started. On 5-6 DAH (larval sizes: respectively, $10.3 \pm 0.6 \mathrm{~mm} \mathrm{TL}$ and $11.6 \pm 0.5 \mathrm{~mm} \mathrm{TL})$, the notochord bending was in progress. At $7 \mathrm{DAH}$ (larval size: $12.3 \pm 0.2 \mathrm{~mm}$ TL), the notochord had completed flexion. The rate of yolk sac exhaustion maintained at the same slower pace seen in the previous stage.

The postflexion stage was characterized by less dramatic morphological changes than those registered in previous stages. It started in 8 DAH (larval size: $13.0 \pm$ $0.3 \mathrm{~mm} \mathrm{TL}$ ) and was still present in the last day of the experiment (29 DAH, larval size: $17.3 \pm 1.1)$. On $8 \mathrm{DAH}$, pelvic fin rays were registered. On $9 \mathrm{DAH}$ (larval size: 13.6 $\pm 0.3 \mathrm{~mm} \mathrm{TL}$ ) the yolk sac was no more macroscopically visible. In the remaining period of study, the external characteristics of the larvae did not morphologically change except for growth in size.

Allometric growth. IP of the six body measurements on the head and corresponding larval age and stage 
of development occurred in the flexion and earlypostflexion stages. A positive allometric growth $(b>$ 1) up to the respective IP followed by a decrease of the growth rate occurred in all six head measurements (Fig. 3). After IP, a positive allometric growth persisted for all measurements, except for head length and maxillary barbels when it was negative $(b<1)$. The IP and larval age for each head measurement were as follows: head length (IP $=12.4 \mathrm{~mm}$ TL, 8 DAH, Fig. 3a), head height (IP $=11.5 \mathrm{~mm}$ TL, 6 DAH, Fig. $3 \mathrm{~b})$, head width (IP $=10.9$ $\mathrm{mm}$ TL, 5 DAH, Fig. 3c), mouth length (IP $=10.9 \mathrm{~mm}$ TL, 5 DAH, Fig. 3d), eye diameter (IP $=10.2 \mathrm{~mm}$ TL, 5 DAH, Fig. 3e) and maxillary barbel length (IP $=11.4 \mathrm{~mm}$ TL, 5 DAH, Fig. 3f).
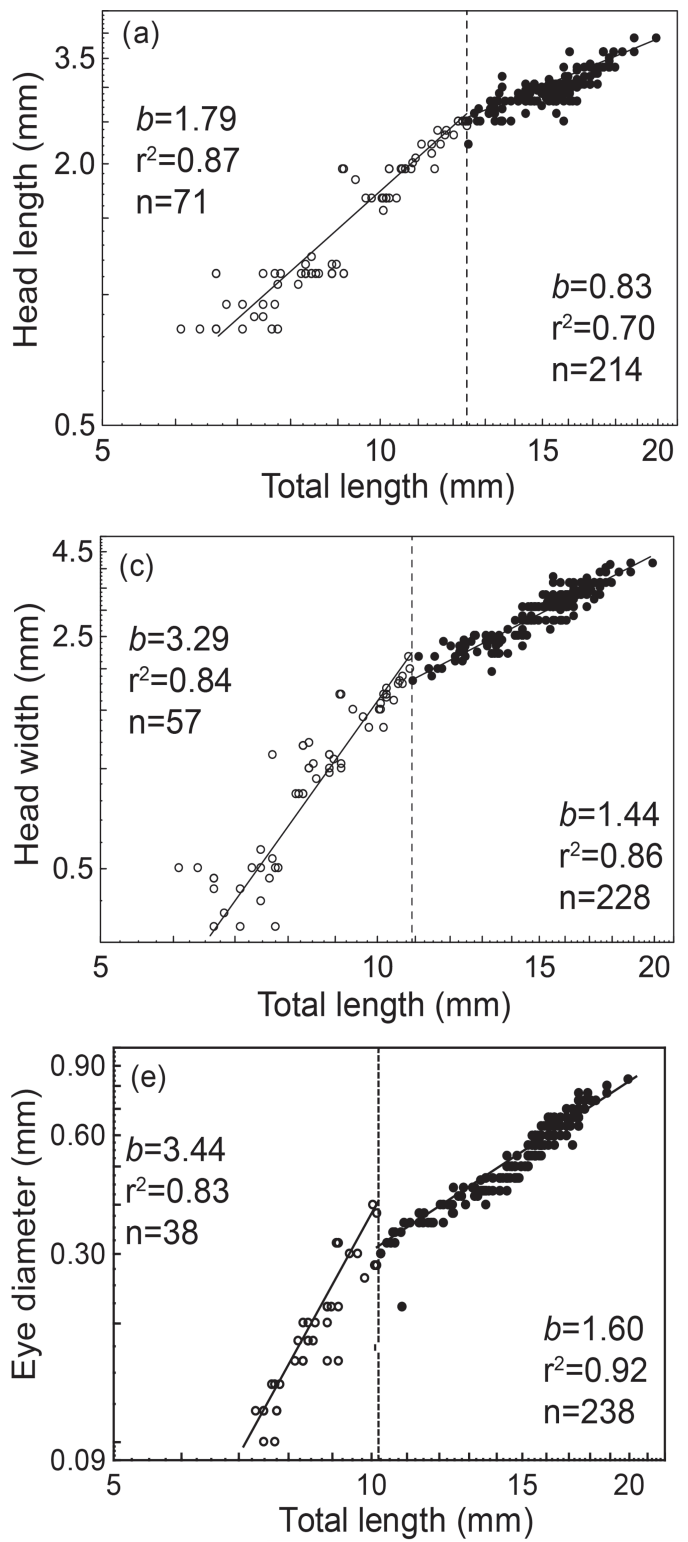

IP and larval age regarding the five measurements on the trunk were as follows: trunk length (IP $=13.5 \mathrm{~mm} \mathrm{TL}$, 9 DAH, Fig. 4a) which had a negative allometric growth before the IP and allometric positive after the IP. Trunk height (IP $=10.9 \mathrm{~mm}$ TL, 5 DAH, Fig. 4b) experienced a positive allometric growth but the lower $b$ seen after IP was statistically isometric. Trunk width presented a positive allometric growth throughout the experimental period and no significant IP (Fig. 4c). Postanal length (IP $=14.4 \mathrm{~mm}$ TL, 11 DAH, Fig. 4d) showed a positive allometric growth before IP and a negative allometric growth after IP. The allometric growth of the yolk sac volume (IP $=11.7 \mathrm{~mm}$ TL, 6 DAH, Fig. 4e) initially was slight negative before IP and then turned strongly negative afterwards.
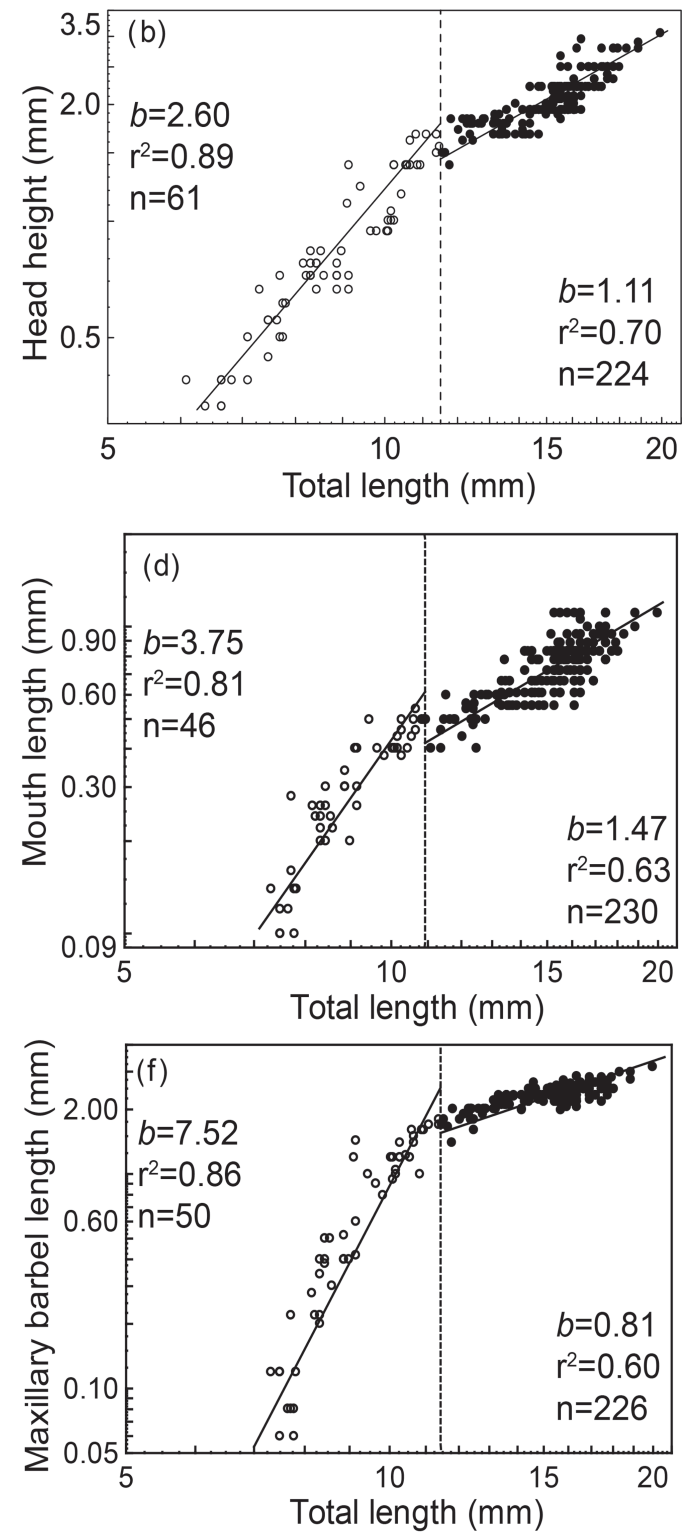

Fig. 3. Allometric growth of measurements on the head of Lophiosilurus alexandri during early development (0-29 days after hatching). The dotted line on total length represents the inflexion point of growth, $b=$ allometric growth coefficient, $\mathrm{r}^{2}=$ coefficient of determination, and $\mathrm{n}=$ number of individuals. (a) head length, (b) head height, (c) head width, (d) mouth length, (e) eye diameter, (f) maxillary barbel length. 

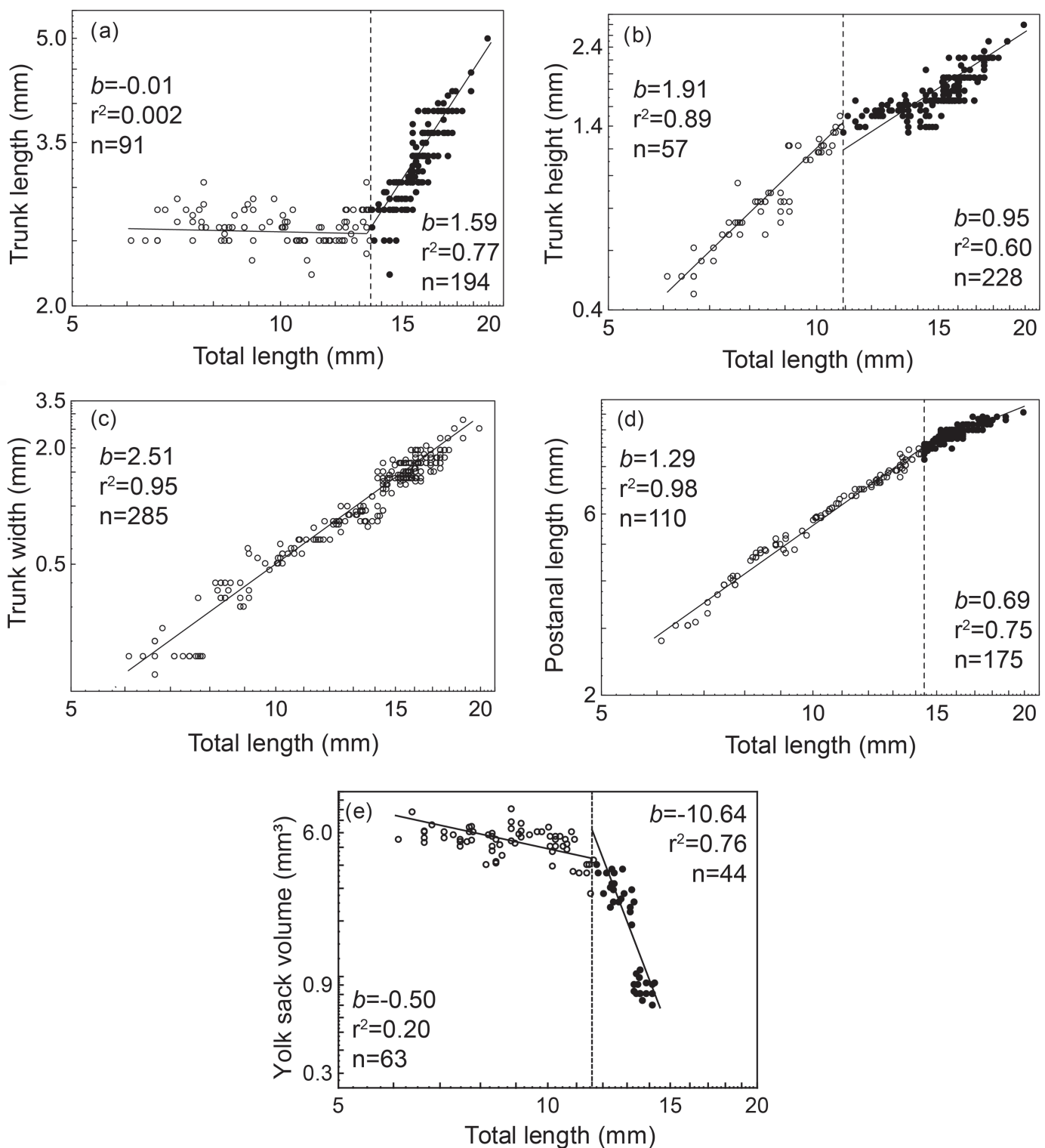

Fig. 4. Allometric growth of measurements on the trunk of Lophiosilurus alexandri during early development (0-29 days after hatching). The dotted line on total length represents the inflexion point of growth, $b=$ allometric growth coefficient, $\mathrm{r}^{2}$ = coefficient of determination, and $\mathrm{n}=$ number of individuals. (a) trunk length, (b) trunk height, (c) trunk width, (d) postanal length, (e) yolk sac volume.

\section{Discussion}

Studies on allometric growth of early life stages in fishes have been done in wild and domestic individuals. Wild early life stage individuals randomly sampled are independent observations as each one was likely born from a different pair. Domestic individuals, on the other hand, might not be independent observations. The number of pairs used in studies of allometric growth of early life stages of domestic fish are often small, less than 6 (e.g. van Snik et al., 1997; Gisbert, 1999; Gisbert \& Doroshov, 2006; Kupren et al., 2014).

When all domestic early life stage individuals are from one pair, as in the present study, they can be used as independent observations but there is no replicate for pair. Thus, the IPs we estimated reflect the traits transmitted from the single pair to its offsprings. When early life stage individuals used in allometric growth studies are from two or more pairs, pairs are replicates, but the individuals are non-independent observations. The use of non-independent individuals in regression analysis increases the likelihood of committing type I error (Grafen \& Hails, 2002). Moreover, if the number of offsprings differs within pairs, the results will be biased towards the pair with the highest number. Thus, a better statistical framework for studies on allometric growth of early life stage of domestic fish are in need because sampling design has not been usually considered in the analyses. 
Intense morphogenesis occurred during early life stages of pacamã larvae resulting in different growth patterns among the body measurements. At hatching, the larval functional systems were mostly undifferentiated, a condition previously pointed out (Guimarães-Cruz et al., 2009). Major morphogenesis in early life is a prevailing condition among teleosts (Osse et al., 1997; van Snik et al., 1997; Nakatani et al., 2001; Guimarães-Cruz et al., 2009, 2014; Kupren et al., 2014). The challenges that fish face in early life are especially arduous because their relatively small size constrains the ability to avoid predators, capture prey, and withstand starvation (Barriga \& Battini, 2009). To overcome adversity, their systems must develop in a timely manner to meet their needs (Gisbert, 1999).

The pacamã larvae presented positive allometric growth in the three dimensions of the head. Positive allometric growth of the head is a common feature during early ontogeny in different teleost orders (van Snik et al., 1997; Gisbert et al., 2002; Gisbert \& Doroshov, 2006), including Siluriformes (Huysentruyt et al., 2009). The fast initial growth of the head might be attributed to the development of the central nervous system, sense organs, and structures related to food capture (Fuiman, 1983; van Snik et al., 1997) as there is a quick depletion of energy reserves accumulated in the yolk sac forcing the fish to obtain exogenous food (Fuiman, 1983). The rapid expansion of the opercular cavity and development of the branchial apparatus, indicating a shift to lower dependence on cutaneous gas exchange, are associated to the increasing importance of the gills (Liem, 1981), which also contribute to the rapid head growth in early ontogeny.

The allometric growth pattern of the head, mouth, trunk, and postanal measurements of pacamã larvae reflects the life style and feeding strategies of adults. The strongly depressed wide head, large mouth, and short body of adult pacamã, which resemble those of benthic marine lophiids (Valentim et al., 2007), are adaptations to allow them to bury in the sand during sit-and-wait behaviour in order to ambush the prey. In early life stages of these studied pacamãs, head length, trunk length, and postanal segment grew slower than head width and trunk width, which then culminate in the typical short and strongly flattened body of the adults (Britski et al., 1984). This is a rather different condition from other pelagic marine and freshwater species whose early life stages show fast development of the postanal segment in order to achieve swimming capabilities for adult life (e.g. bluefin tuna and yellowfin tuna: Osse \& van den Boogaart, 2004; piracanjuba: Nogueira et al., 2014). Larvae of pacamã as a slow-moving, bottom-dweller (Sato et al., 2003) does not require the same swimming capabilities as those of pelagic fish.

Vision is likely more important during pacamã larval stage than later in life. The adult pacamã has relatively small eyes whose diameter fits 20 to 24 times in the head length (Britski et al., 1984). In early life, however, the eyes are relatively larger such that the head length is only 6 times the eye diameter (GCG Mello, unpublished data). The fast initial growth of the eye (IP at flexion stage, present study) parallels a differentiation of the retinal pigment epithelium and retinal layers with rods and cones present as early as in preflexion stage, 3 DAH (Guimarães-Cruz et al., 2009). The fast development of functional eyes during early larval period, associated to that of the maxillary barbels, promotes ability to detect prey and predators (Barriga \& Battini, 2009) increasing the survival chances of early life individuals.

Maxillary barbels are important organs in early life of pacamãs and showed the highest growth rate among the body measurements evaluated in the present study. The very fast initial growth of maxillary barbels (IP at flexion stage) associated to the presence of their tactile and taste structures (Sakata et al., 2001) implies that they have an important role in searching for food during the initial phases of development. Additionally, neuromast wattles are present as early as $5 \mathrm{DAH}$, flexion stage, in pacamã (Guimarães-Cruz et al., 2009). The functional importance of the maxillary barbels apparently reduces as pacamã grows, and in adults, they are near vestigial.

The size at $11 \mathrm{~mm} \mathrm{TL}$, corresponding to $5 \mathrm{DAH}$, in the flexion stage, is key in pacamã ecology. Although the digestive system is not yet fully differentiated (GuimarãesCruz et al., 2009), the IP of important early structures related to feeding, such as mouth length, maxillary barbel length and eye diameter, occurred around $11 \mathrm{~mm} \mathrm{TL}$ in the pacamãs of the present study. At this size, pacamãs already have filiform teeth, a pharyngeal tooth plate, and fully developed eyes (Guimarães-Cruz et al., 2009). They are likely ready to search and capture for prey, which is corroborated by the much faster yolk sac consumption after $11 \mathrm{~mm}$ TL. Moreover, experimental exogenous feeding initiates at this length (Pedreira et al., 2008). The period between the IP of mouth length and the end of the yolk sac could be linked to the development and improvement of suction and prey capture before relying fully on exogenous energy for survival (Hunt von Herbing et al., 1996). Lastly, the digestive system of the pacamã is fully differentiated with the development of gastric glands (Guimarães-Cruz et al., 2009) at the size of $13.5 \mathrm{~mm}$ TL when the yolk sac is about to end and positive allometric growth of trunk length starts.

Oxygen needs during the initial growth of fishes peak at the onset of exogenous feeding (Kamler, 2002). Thus, the increasing rate of yolk sac depletion indicates a larger energy expenditure required by early larvae of pacamã to cope with initial feeding efforts.

In conclusion, the higher growth rates of sensory structures (eyes and maxillary barbels) and the acquired ability to capture prey (as indicated by mouth length) found in larvae of pacamã strengthen the hypothesis of growth priorities in which the most essential organs develop first, followed by those of lower priority for survival. 


\section{Acknowledgments}

We thank Yoshimi Sato for supplying the fish and allowing us to use the facilities of the Centro Integrado de Recursos Pesqueiros e Aquicultura, CODEVASF, Três Marias, MG, Brazil. We would also like to thank Lorena B. Nogueira for her help in obtaining the data used in this paper, and to PUC Minas (Project 2002/07 TLE) for providing financial support.

\section{References}

Balon, E. K. 1975. Reproductive guilds of fishes: a proposal and definition. Journal of the Fisheries Research Board of Canada, 32: 821-864.

Balon, E. K. 1999. Alternative ways to become a juvenile or a definitive phenotype (and on some persisting linguistic offenses). Environmental Biology of Fishes, 56: 17-38.

Barriga, J. P. \& M. A. Battini. 2009. Ecological significances of ontogenetic shifts in the stream-dwelling catfish, Hatcheria macraei (Siluriformes, Trichomycteridae), in a Patagonian river. Ecology of Freshwater Fish, 18: 395-405.

Blaxter, J. H. S. \& G. Hempel. 1966. Utilization of yolk by herring larvae. Journal of the Marine Biological Association of the UK, 46: 219-234.

Britski, H. A., Y. Sato \& A. B. S. Rosa. 1984. Manual de identificação de peixes da região de Três Marias(com chaves de identificação para os peixes da bacia do São Francisco). Brasília, DF, Câmara dos Deputados/CODEVASF, 143p.

Fuiman, L. A. 1983. Growth gradients in fish larvae. Journal of Fish Biology, 23: 117-123.

Gisbert, E. 1999. Early development and allometric growth patterns in Siberian sturgeon and their ecological significance. Journal of Fish Biology, 54: 852-862.

Gisbert, E. \& S. I. Doroshov. 2006. Allometric growth in green sturgeon larvae. Journal of Applied Ichthyology, 22(Suppl. 1): 202-207.

Gisbert, E., G. Merino, J. B. Muguet, D. Bush, R. H. Piedrahita \& D. E. Conklin. 2002. Morphological development and allometric growth patterns in hatchery-reared California halibut larvae. Journal of Fish Biology, 61: 1217-1229.

Grafen, A. \& R. Hails. 2002. Modern statistics for the life sciences. Oxford, Oxford University Press, 351p.

Guimarães-Cruz, R. J., J. E. Santos, Y. Sato \& V. C. Veloso-Júnior. 2009. Early development stages of the catfish Lophiosilurus alexandri Steindachner, 1877 (Pisces: Pseudopimelodidae) from the São Francisco River basin, Brazil. Journal of Applied Ichthyology, 25: 321-327.

Guimarães-Cruz, R. J., V. C. Veloso-Júnior, N. G. Sales, D. A. A. Oliveira \& J. E. Santos. 2014. Allometric growth patterns in hatchery-reared larvae of the catfish Lophiosilurus alexandri (Pisces: Pseudopimelodidae). Arquivo Brasileiro de Medicina Veterinária e Zootecnia, 66: 284-288.

Hunt von Herbing, I., T. Miyake, B. K. Hall \& R. G. Boutilier.1996. Ontogeny of feeding and respiration in larval Atlantic cod Gadus morhua (Teleostei, Gadiformes): I. Morphology. Journal of Morphology, 227: 15-35.

Huysentruyt, F., B. Moerkerke, S. Devaere \& D. Adriaens. 2009. Early development and allometric growth in the armoured catfish Corydoras aeneus (Gill, 1858). Hydrobiologia, 627: 45-54.
Instituto Chico Mendes de Conservação da Biodiversidade (ICMBio). 2014. Lista de espécies ameaçadas. Available from: http://www.icmbio.gov.br/portal/biodiversidade/faunabrasileira/lista-de-especies.html. (13 January 2014).

Kamler, E. 2002. Ontogeny of yolk-feeding fish: an ecological perspective. Reviews in Fish Biology and Fisheries, 12: 79103.

Koumoundouros, G., Z. Kiriakos, P. Divanach \& M. Kentouri. 1995. Morphometric relationships as criteria for the evaluation of larval quality of gilthead sea bream. Aquaculture International, 3: 143-149.

Kupren, K., M. Prusinska, D. Zarski, S. Krejszeff \& D. Kucharczyk. 2014. Early development and allometric growth in Nannacara anomala Regan, 1905 (Perciformes: Cichlidae) under laboratory conditions. Neotropical Ichthyology, 12: 659-665.

Liem, K. F. 1981. Larvae of air-breathing fishes as countercurrent flow devices in hypoxic environments. Science, 211: 11771179.

López, C. M. \& E. V. Sampaio. 2000. Sobrevivência e crescimento larval do pacamã Lophiosilurus alexandri Steindachner 1876 (Siluriformes, Pimelodidae) em função de três densidades de estocagem em laboratório. Acta Scientiarum, Biological Sciences, 22: 491-494.

Luz, R. K., J. C. E. Santos, M. M. Pedreira \& E. A. Teixeira. 2011. Effect of water flow rate and feed training on "pacamã" (Siluriforme: Pseudopimelodidae) juvenile production. Arquivo Brasileiro de Medicina Veterinária e Zootecnia, 63: 973-979.

Müller, U. K. \& J. J. Videler. 1996. Inertia as a 'safe harbour': do fish larvae increase length growth to escape viscous drag? Reviews in Fish Biology and Fisheries, 6: 353-360.

Nakatani, K., A. A. Agostinho, G. Baumgartner, A. Bialetzki, P. V. Sanches, M. C. Makrakis \& C. S. Pavanelli. 2001. Ovos e larvas de peixes de água doce: desenvolvimento e manual de identificação. Maringá, EDUEM, 378p.

Nogueira, L. B., A. L. Godinho \& H. P. Godinho. 2014. Early development and allometric growth in hatchery-reared characin Brycon orbignyanus. Aquaculture Research, 45: 1004-1011.

Oliveira, E. C., A. Bialetzki \& L. F. Assakawa. 2008. Morphological development of Hypophthalmus fimbriatus and H. marginatus post-yolk-sac larvae (Siluriformes: Pimelodidade). Zootaxa, 1707: 37-48.

Osse, J. W. M. \& J. G. M. van den Boogaart. 1995. Fish larvae, development, allometric growth, and the aquatic environment. ICES Marine Science Symposia, 201: 21-34.

Osse J. W. M. \& J. G. M. van den Boogaart. 2004. Allometric growth in fish larvae: timing and function. Pp. 167-194. In: Govoni J. J. (Ed.). The development of form and function in fishes and the question of larval adaptation: proceedings of the "Symposium on the morphological development and physiological function in fishes" held in Bergen, Norway, 2002. Bethesda, Maryland, American Fisheries Society. (American Fisheries Society Symposium, 40).

Osse, J. W. M., J. G. M. van den Boogaart, G. M. J. van Snik \& L. van der Sluys. 1997. Priorities during early growth of fish larvae. Aquaculture, 155: 249-258.

Pedreira, M. M., R. K. Luz, J. C. E, Santos, E. V. Sampaio \& R. S. F. Silva. 2009. Biofiltração da água e tipos de substrato na larvicultura do pacamã. Pesquisa Agropecuária Brasileira, 44: 511-518. 
Pedreira, M. M., E. V. Sampaio, J. C. E. Santos \& A. V. Pires. 2012. Larviculture of two neotropical species with different distributions in the water column in light- and dark-colored tanks. Neotropical Ichthyology, 10: 439-444.

Pedreira, M. M., J. C. E. Santos, E. V. Sampaio, F. N. Pereira \& J. L. Silva. 2008. Efeito do tamanho da presa e do acréscimo de ração na larvicultura de pacamã. Revista Brasileira de Zootecnia, 37: 1144-1150.

Safran, P. 1992. Theoretical analysis of the weight-length relationship in fish juveniles. Marine Biology, 112: 545-551.

Sakata, Y., J. Tsukahara \& S. Kiyohara. 2001. Distribution of nerve fibers in the barbels of sea catfish Plotosus lineatus. Fisheries Science, 67: 1136-1144.

Sanches, P. V., K. Nakatani \& A. Bialetzki. 1999. Morphological description of the developmental stages of Parauchenipterus galeatus (Linnaeus, 1766) (Siluriformes, Auchenipteridae) on the floodplain of the upper Paraná River. Revista Brasileira de Biologia, 59: 429-438.

Santos, J. C. E. \& R. K. Luz. 2009. Effect of salinity and prey concentrations on Pseudoplatystoma corruscans, Prochilodus costatus and Lophiosilurus alexandri larviculture. Aquaculture, 287: 324-328.

Santos, H. B., E. V. Sampaio, F. P. Arantes \& Y. Sato. 2013. Induced spawning and reproductive variables of the catfish Lophiosilurus alexandri Steindachner, 1876 (Siluriformes: Pseudopimelodidae). Neotropical Ichthyology, 11: 607-614.
SAS Institute. 1990. SAS/STA User's guide: version $6,4^{\text {th }}$ ed. Cary, NC, SAS Institute, 1786p., $2 \mathrm{v}$.

Sato, Y., N. Fenerich-Verani, A. P. O. Nuñer, H. P. Godinho \& J. R. Verani. 2003. Padrões reprodutivos de peixes da bacia do São Francisco. Pp. 229-274. In: Godinho, H. P. \& A. L. Godinho (Orgs.). Águas, peixes e pescadores do São Francisco das Minas Gerais. Belo Horizonte, Ed. PUC-Minas.

Sato, Y. \& H. P. Godinho. 1999. Peixes da bacia do rio São Francisco. Pp. 401-413. In: Lowe-McConnel, R. H. (Ed.). Estudos ecológicos de comunidades de peixes tropicais. Tradução: Vazzoler, A. E. A. de M., A. A. Agostinho \& Cunnigham, P. T. M. São Paulo, Edusp (Coleção Base).

Valentim, M. F. M., E. P. Caramaschi \& M. Vianna. 2007. Biologia e ecologia de peixes do gênero Lophius (Lophiidae, Lophiiformes), com ênfase em Lophius gastrophysus Miranda-Ribeiro, 1915: status atual. Oecologia Brasiliensis, 11: 503-520.

van Snik, G. M. J., J. G. M. van den Boogaart \& J. W. M. Osse.1997. Larval growth patterns in Cyprinus carpio and Clarias gariepinus with attention to the finfold. Journal of Fish Biology, 50: 1339-1352.

Submitted October 28, 2014

Accepted July 10, 2015 by Andrea Bialetzki

Published December 15, 2015 